\title{
"Bibliotekssagen trænger til Organisation"
}

\section{Folkebibliotekerne i Danmark 1880-1920}

Af Laura Skouvig

\section{Indledning}

Folkebibliotekernes historie er ikke et ubeskrevet felt herhjemme. Slet ikke for årene mellem 1880 og 1920, hvor ideen om det moderne folkebibliotek i Danmark skabtes. Det var først og fremmest spørgsmålet om indførelsen af en god og hensigtsmæssig organisation, der kendetegnede denne skabelsesproces. Ăret 1909 regnes traditionelt som afgørende for indførelsen af den organisationsform, som siden hen er blevet accepteret som den rigtige. I dette år afholdtes biblioteksmødet i Ârhus, hvor Det kongelige Biblioteks overbibliotekar, H. O. Lange $\mathrm{i}$ foredraget Bibliotekssagen uden for København slog til lyd for det synspunkt, at en bedre og mere hensigtsmæssig organisation skulle bringe bibliotekerne videre. Afsættet var, at der ikke eksisterede en egentlig organisation, og at "Bibliotekssagen trænger til Organisation". ${ }^{1}$ For Lange var det essentielle spørgsmål den ydre organisation mellem bibliotekerne, som han forstod som et samarbejde mellem forskellige bibliotekstyper. Den indre organisation af bibliotekernes bøger og arbejdsgange, bibliotekernes fysiske placering i bygninger, samt hvordan disse lokaler blev indrettet, var ikke videre centrale punkter for ham. Lange nævnte dem ganske vist i foredraget som elementer i bibliotekernes organisation, men de blev ikke nærmere uddybet. Den indre organisation og indretningen kan ikke desto mindre ses som væsentlige

Laura Skouvig, ph.d.; Danmarks Biblioteksskole, Birketinget 6, 2300 Kobenhavn S. 
aspekter af organisationstanken. Især organisationen af bøgerne og arbejdsgangene blev flittigt diskuteret, medens placeringen og indretningen af bibliotekerne tilsyneladende ikke var genstand for større diskussion. Ikke desto mindre var rådgivningen om en hensigtsmæssig indretning af bibliotekslokaler en væsentlig del af Statens Bogsamlingskomités arbejde, og det forekommer derfor naturligt at sætte den ydre organisation i forbindelse med den diskurs (forståelsesramme), som etableredes omkring placeringen og indretningen af bibliotekslokalerne. Netop dette er emnet for denne artikel.

Organisationen af bibliotekerne er tidligere behandlet som en del af folkebibliotekernes generelle udvikling. I sin bog De danske folkebibliotekers historie 1876-1940 fra 1962 beskriver Harald Hvenegaard Lassen nøje den udvikling, som førte fra de gamle, små og usle sognebogsamlinger til de nye moderne folkebiblioteker. En nærmere analyse af de små sognebogsamlingers vanskelige kår gives af Marton de Hartyani med udgangspunkt i sognebiblioteksundersøgelsen fra 1885. Steffen Høgh behandler i en artikel indgående de stridigheder, der var mellem 'bogsamlingsfolket' og folkebibliotekarerne som de to retninger inden for biblioteksarbejdet i perioden fra $1915 \mathrm{og}$ frem til bibliotekslovens vedtagelse i 1920 (og stridens endelige afslutning i 1928). Striden indgår som et mindre element i Hvenegaard Lassens fremstilling, der beskriver den fremadskridende udvikling fra det gammeldags og umoderne (repræsenteret ved bogsamlingsfolket) til det nye og moderne (repræsenteret ved folkebibliotekarerne). ${ }^{2}$ De stærke positioneringer og modsætninger i perioden 1880-1920 udmøntedes i livlige diskussioner af en række temaer, som er væsentlige for vores forståelse af folkebibliotekernes ideologiske forankring $\mathrm{i}$ dag. De centrale diskussioner drejede sig om bogvalget i bibliotekerne, bibliotekernes organisation, bibliotekarens opgaver og synet på låneren. Diskussionen om bibliotekernes samfundsmæssige opgave blev en integreret del af disse fire temaer. ${ }^{3}$

For både Hvenegaard Lassen og Høgh er forskellen mellem folkebogsamlingerne og folkebibliotekerne entydig og håndgribelig som en del af en fælles forståelsesramme inden for biblioteksverdenen. Bruges betegnelsen folkebogsamling, er der ikke megen tvivl 
om, at der hentydes til en gammeldags og uprofessionel måde at drive biblioteksvirksomhed på - en sprogbrug, der blev etableret nærmest samtidig med Dansk Biblioteksforening i 1916. Udgangspunktet for denne artikel er derfor, at forskellen mellem sognebogsamlingerne og folkebibliotekerne var et led i et ideologisk opgør om den 'gode' måde at drive biblioteksvirksomhed på, og betegnelserne bruges derfor i flæng. Generelt var brugen af bibliotek eller bogsamling (med forstavelserne folke- eller sogne-) i perioden så tilpas flydende og dækkende alle typer af biblioteker, at en nutidig ikke-konsekvent brug af ordene vil kunne forklares derudfra.

Synet på folkebibliotekernes historie, som det kommer til udtryk i denne artikel, er inspireret af den franske teoretiker Michel Foucault. Frem for at se historien som en fremadskridende proces, der medfører et stadigt højere udviklingsniveau, forstår han den historiske udvikling som en transformationsproces, der er præget af diskontinuitet og brud mellem forskellige systemer af viden. Disse brud medfører opkomsten af nye diskurser (forståelsesrammer), som definerer en bestemt form for viden som det, der er alment accepteret, og som afskærer konkurrerende forståelsesrammer. Den bestemte form for viden er tæt knyttet til magt, men ikke magt som en bestemt klasses overherredømme over en anden. I stedet er der tale om en strategi, der kan tages i anvendelse. Magten er knyttet til systemer frem for til enkeltpersoner og opererer gennem kontrol og disciplinering. ${ }^{4}$ Inspirationen fra Foucault betyder, at folkebibliotekernes udvikling ikke ses som en udvikling fra et lavere stadium (folkebogsamlingerne) til det højere og bedre som blev fundamentet for vore dages folkebiblioteker. I stedet ses folkebibliotekerne som en del af den samfundsmæssige transformation. Folkebibliotekernes historie kan siges at rumme et brud mellem forskellige forståelsesrammer for organiseringen af bibliotekerne og mellem forskellige former for udøvelse af magt.

Emnet for denne artikel er bruddet mellem forskellige praksisser for organiseringen af biblioteker. For at undersøge bruddet mellem disse praksisser er det centrale den måde, som organisationen omtaltes på. Artiklen vil som følge heraf ikke i væsentlig grad beskæf- 
tige sig med, hvilke personer der ytrede sig om bibliotekernes organisation, men med de ytringer som blev fremsat. Kernen til forståelsen af bibliotekernes organisation ligger netop i disse ytringer, og ved at afdække relationerne mellem dem fremdrages to forskellige organisationsformer. Dette er emnet for de forste to afsnit af artiklen, der behandler bibliotekslandskabet omkring 1880 og biblioteksvæsenet, som det så ud med bibliotekslovens vedtagelse i 1920 . En væsentlig relation er, hvorledes bibliotekerne fordelte sig i forhold til hinanden som forskellige typer med afgrænsede opgaver, og hvordan magten manifesterede sig $\mathrm{i}$ de to organiseringspraksisser. Gennem forskellene $\mathrm{i}$ fordelingen af bibliotekerne og forskellene $\mathrm{i}$ magtens fordeling tydeliggøres bruddet mellem de to organiseringspraksisser.

Dernæst undersøges det, hvorledes dette brud manifesterede sig i fordelingen af bibliotekerne. Interessen koncentreres om en undersøgelse af inddelingen og afgrænsningen af det rent fysiske område for biblioteket, hvor det tildeltes enten en særlig bygning eller som minimum et særligt lokale. På denne måde indkredses bibliotekets etablering i byens rum, og hvilke funktioner biblioteket blev tilkendt gennem dets udsondring som et afgrænset rum. Bibliotekets lokaler (eller bygning) skulle endvidere inddeles på bestemte måder, og denne videre inddeling understregede de funktioner, som biblioteket skulle indtage.

Artiklen er baseret på materiale fra debatter i Bogsamlingsbladet (udgivet fra 1906 af foreningen Danmarks Folkebogsamlinger) og i enkelte andre tidsskrifter og aviser, som primært dækker perioden før 1906. Biblioteksloven fra 1920 med tilhørende bekendtgørelser er i denne sammenhæng en væsentlig kilde, og desuden inddrages materiale fra de forskellige bogsamlingskomiteer i perioden 1880 1920. Et andet væsentligt kildegrundlag er de håndbøger, der blev udgivet i perioden 1900-1920.

\section{Bibliotekslandskabet 1880}

Bibliotekernes organisering omkring 1880 drejede om de enkelte biblioteker, der eksisterede uafhængigt af hinanden. Den generelle metode, som anvendtes i samtiden ved beskrivelsen af bogsamling- 


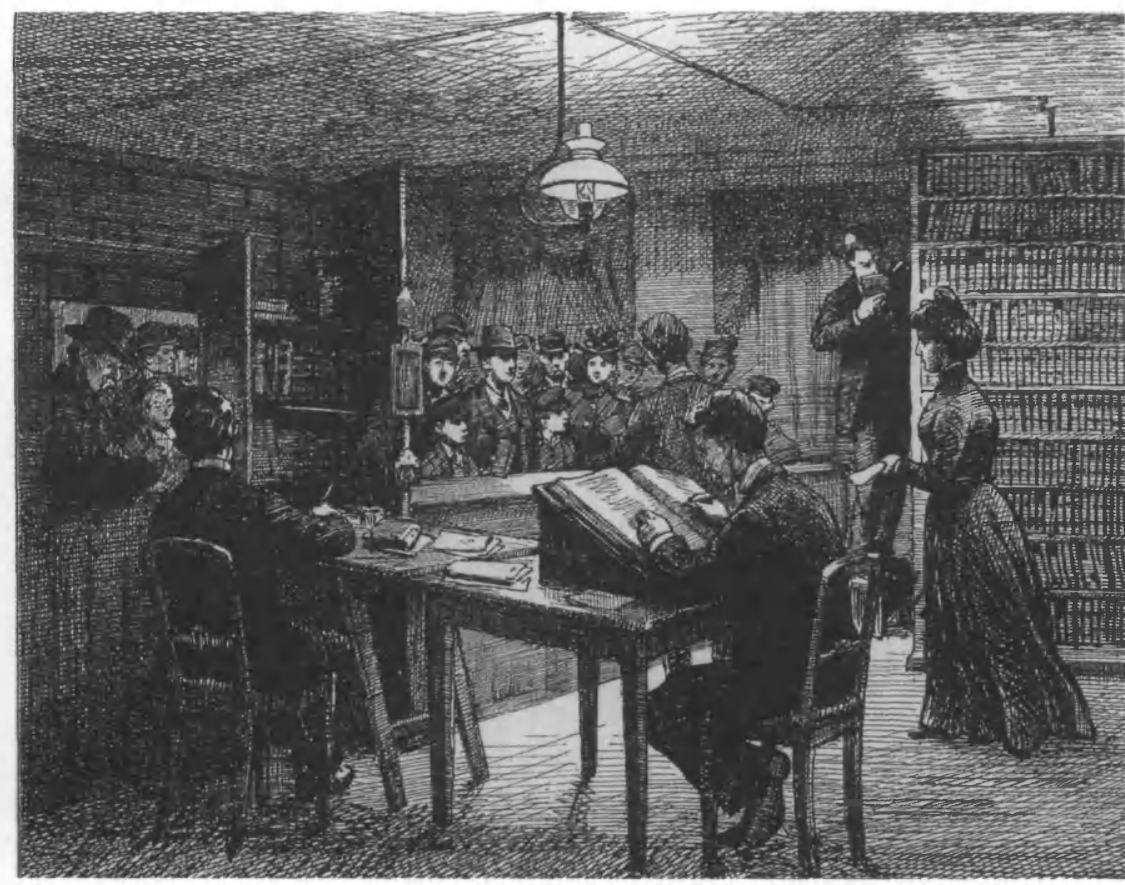

Udlånssalen på Norrebro. Skranken er en udleveringsdisk med en luge. Her kunne lånerne fremkomme med deres onsker, som bibliotekarerne efterkom. Bogerne hentede bibliotekarerne på reolerne bag skranken, hvortil kun bibliotekarerne havde adgang. Sognebibliotekernes pladsforhold var meget anderledes. Der var sjeldent tale om et selvstendigt lokale, og bogerne opbevaredes $i$ lukkede skabe. (Efter tegning af Tom Petersen (Frem 1903-04). Fra J. Aarsbo: Bibliotekerne og Samfundet, 1935, s. 180)

erne omkring 1880, kan kaldes den geografiske, idet den afspejlede den generelle tredeling af samfundet i landet, købstæderne og hovedstaden. ${ }^{5}$ Interessen var vendt mod bogsamlingerne på landet, og købstæderne nævntes kun for så vidt, at deres biblioteksudbud havde en betydning for landet. Enten blev dette biblioteksudbud betragtet som en fare på grund af den underlødige litteratur, eller det blev anset som en fordel på grund af de stærkere impulser, der kom fra købstædernes kulturelle liv. ${ }^{6}$ I købstæderne fandtes en mangfoldighed af lejebiblioteker og foreningsbiblioteker, hvoraf de førstnævnte jævnligt kritiseredes for deres dårligt sammensatte bog- 
bestand, medens de sidstnævnte som regel kun var for medlemmerne af foreningen og typisk havde et andet formål end biblioteksdrift (f. eks. håndværkerforeninger og lign.). Selve købstadsbogsamlingerne grundlagdes med biblioteket for øje, og sådanne fandtes $i$ en række danske købstæder omkring $1880 .^{7}$ Også København havde en mængde lejebiblioteker og foreningsbiblioteker, og 1885 grundlagdes de københavnske kommunebiblioteker med biblioteksudbuddet som formål og målsætning. ${ }^{8}$ Forskellen mellem de københavnske kommunebiblioteker og sognebibliotekerne på landet var, at byrådet havde taget initiativet til bibliotekernes oprettelse for siden at overdrage det videre initiativ i forbindelse med driften til bibliotekarerne. Foregangsmændene ved oprettelsen af sognebibliotekerne repræsenterede gerne det videre initiativ i forbindelse med driften af biblioteket ved at fungere som bibliotekar.

Sognebiblioteksundersøgelsen fra 1885 søgte at kortlægge antallet og spredningen af bogsamlingerne for amter, herreder og sogne og fulgte trop i forhold til tre eksisterende fremstillinger af sognebibliotekerne fra 1876, 1878 og 1880. ${ }^{9}$ Undersøgelsesfelterne i alle undersøgelserne var tilknytningen til sognet, bibliotekernes levealder, antal og størrelse. Størrelsen blev målt i forhold til kontingentet pr. person, antallet af bind, antallet af medlemmer og antallet af udlån, hvis en sådan oversigt var mulig. ${ }^{10}$ Det deraf fremkomne billede vurderedes ikke negativt, da selve oprettelsen af disse bogsamlinger blev anset for at være et direkte vidnesbyrd om, at læselysten og trangen til oplysning var et udbredt fænomen blandt landbefolkningen, og trods den ikke overvældende størrelse af den enkelte bogsamling var det samlede antal gunstigt. Forholdet mellem størrelse og antal var problematisk, da det store antal af bogsamlinger eksisterede på bekostning af størrelsen, der blev set som altafgørende. Som følge deraf var der bred enighed om nødvendigheden af sammenslutninger af de små bogsamlinger. ${ }^{11}$ Formålet med disse sammenslutninger var betinget af ønsket om at sikre bogsamlingernes fortsatte eksistens.

Sognebiblioteket var langt fra en entydig størrelse, og en klar definition af det blev ikke givet. Tilknytningen til sognet blev etable- 
ret på flere måder. Der kunne være tale om ét bibliotek i sognet og kun gældende for sognets beboere, men der kunne sagtens være flere biblioteker i samme sogn, eller endda et bibliotek for flere sogne. ${ }^{12}$ Alle disse forskellige indretninger benævnedes som regel sognebiblioteker. Under betegnelsen sognebibliotek medtog komiteen, som var nedsat af den Raben-Levetzauske Fond, f.eks. biblioteker i arbejderforeninger, industriforeninger og brugsforeninger, men ikke bogsamlinger på højskoler eller privates bogsamlinger, der ellers var åbne for udlån til almuen. En række andre bogsamlinger hørte ligeledes ind under sognebiblioteksbetegnelsen - som lånebogsamlinger og læseforeninger - medens skolebogsamlinger var en kategori for sig selv. Hvor skolebogsamlinger næsten kategorisk afvistes at høre ind under sognebiblioteksbetegnelsen, skelnedes der ikke konsekvent mellem børne- og sognebogsamlinger. Ârsagen hertil lå i det forhold, at både børn og voksne læste bøgerne fra børnebogsamlingen. En sådan kunne efterhånden gå over til at blive en voksenbogsamling og tolkedes derfor som et glimrende middel til at skabe trivsel i de egentlige sognebogsamlinger. Det usikre i betegnelsen sognebibliotek gjaldt ligeledes ejerformen, hvor betegnelsen sogn langt fra betød, at biblioteket var sognets ejendom endsige grundlagt på sognets foranledning. Betegnelsen relaterede sig blot til, at biblioteket tilhørte sognets beboere og ikke bidragyderne. Betegnelsen var i og for sig ligegyldig, for uanset om der var tale om en læseforening eller et sognebibliotek, så ville begge medføre en fornøjelig og god anvendelse af fritiden, og dette var hovedformålet.

Udgangspunktet for bogsamlingen var ikke sognet, men kredsen. Kredsen havde flere betydninger som kredsen af initiativtagere, kredsen af medlemmer og kredsen af brugere, for hvem bogsamlingen var tænkt. Fælles for disse kredse var deres egenskab af at være private som en modsætning til sognerådet og staten. ${ }^{14}$ Den traditionelle modsætning mellem det private og det offentlige var dog ikke central. Sognebiblioteket var ikke egentlig konstrueret som et offentligt anliggende, men var knyttet til det private og blev set som en forlængelse af det private hjem. Først i kraft af benyttelsen gennem kredsen af brugere kom der et vist offentlighedsaspekt over bibliotekerne. 
De forskellige kredse, som udgjorde fundamentet for bogsamlingen, havde visse overlap, men det var ikke en selvfølge. Kredsene kan ses som liggende i hinanden som koncentriske cirkler, hvor den inderste (og mindste) var kredsen af initiativtagere. Den lidt større kreds udgjordes af medlemmerne, som igen var omkranset af den yderste og største kreds af lånere. Kredsene differentieredes gennem forskellen mellem de dannede og de uoplyste. Initiativtagerne var entydigt at finde blandt dannede mennesker, medens kredsen af lånerne var uoplyst. En yderligere differentiering lå i den økonomiske formåen, hvor der sattes en grænse mellem de ubemidlede, som skulle nyde godt af bogsamlingens tilbud, medens de formuende var at finde blandt initiativtagerne. Initiativtagerne behøvede ikke at høre til kredsen af medlemmer eller kredsen af lånere, og på tilsvarende vis var kredsen af medlemmer ikke entydigt identisk med kredsen af lånerne. Forskellen mellem kredsen af medlemmer og kredsen af lånere var betinget af kontingentets struktur. Kontingentet dækkede medlemskab af en forening, hvortil der var knyttet et bibliotek. Medlemmerne betalte for at fă bøgerne i cirkulation, medens lånerne betalte for at låne bøgerne fra biblioteket. Kredsen af medlemmer og kredsen af lånere var oftest identiske, men adskilt ved hjælp af de differentierede kontingentsatser afhængig af formueforhold. De fattigste lånere var ikke medlemmer, men burde have gratis adgang. ${ }^{15}$

Det enkelte medlems kontingent finansierede bogsamlingen, og kontingentet repræsenterede derfor et væsentligt magtinstrument for medlemmet. Utilfredshed med bogsamlingen af den ene eller den anden art kunne medføre manglende betaling af kontingentet og faldende indtægter for bogsamlingen. Det var kontingentet, der udgjorde den afgørende forbindelse mellem medlemmerne og foreningen - ikke bogen. ${ }^{16}$ Driften af biblioteket var et spørgsmål om $ø$ konomi, hvor omdrejningspunktet var den gratis drift (af mere eller mindre frivillige kræfter som lærer eller præst) over for det ikke-gratis udlån. Økonomien var forudsætningen for bogsamlingens fortsatte eksistens, og det der sikrede muligheden for en ubrudt og fortsat udbredelse af oplysning til sognets beboere. Kontingentet kunne suppleres ved understøttelse fra det lokale sogneråd eller an- 
dre mulige understøttelseskilder som den lokale sparekasse, den Raben-Levetzauske Komite eller Udvalget til Folkeoplysningens Fremme. Ved tilskud fra det lokale sogneråd blev det anset for en fordel at give dette adgang til "... et slags Kontrol enten selv eller gjennem Skolekommissionen ..." med midlernes forsvarlige brug. ${ }^{17}$

En stram organisation af bogsamlingen fandtes centreret omkring den valgte bestyrelse eller komité, som ledte bogsamlingen fra initiativet til oprettelsen, forestod selve oprettelsen og den daglige drift. Princippet for sammensætningen af denne bestyrelse havde sin rod i opfattelsen af generalforsamlingen som den fornemste demokratiske styreform, hvor dannede mænd valgte frit blandt egen kreds. Generalforsamlingen (dvs. medlemmerne) var bogsamlingens fremmeste magtinstans, medens bestyrelsen kunne ses som udøvende magten i den daglige drift gennem bogvalget. Typisk var både præsten og læreren (eller en af dem) medlem af bestyrelsen. En valgt bestyrelse og formand sikrede interessen blandt sognets beboere for bogsamlingen, hvorfor organisationens omdrejningspunkt var bestyrelsen og dennes formand. Almindeligvis fungerede læreren som bibliotekar, men dette blev anset som uheldigt, da det kunne medføre et sammenbrud i bogsamlingens videre arbejde, når lærerembedet af den ene eller anden årsag stod ledigt. I disse tilfælde betragtedes det som en yderligere fordel at opnå et tilskudsbestemt tilsyn fra sognerådet for derigennem at sikre bogsamlingens fortsatte beståen. ${ }^{18}$ Bogsamlingens fortsatte eksistens var ikke udelukkende bundet til en organisatorisk ramme for bogsamlingen, men også til en økonomisk ramme.

Bogsamlingerne var et middel til at sprede oplysning blandt almuen på landet, der var nedsunket $\mathrm{i}$ sanselighed og kun interesserede sig for den materielle side af livet. Især ungdommen var i farezonen, da den kun søgte den hurtige fornøjelse i kortspil og lignende adspredelser. ${ }^{19}$ Kampen mod materialismen førtes gennem læselysten og vækkelsen af denne som en første betingelse for bibliotekets eksistens. Læselysten instrumentaliseredes i bekæmpelsen af materialismen ved at opdele den i en underholdende, en belærende og en politisk læselyst. På denne vis medførte læselysten en berigelse af ånden på materialismens bekostning. En følgesvend 
til materialismen var usædeligheden og det moralske forfald. Her var det ikke længere nok med læselysten. Også det, som præsenteredes for brugeren af biblioteket - altså bøgerne - måtte inddrages som et led i kampen. Det betonedes stærkt, at bøger, der pirrede fantasien, men som sløvede andre åndsevner, ikke skulle findes $\mathrm{i}$ bogsamlingen. Det var ikke kun almuen, der var i farezonen. Selv om dens åndsevner generelt vurderedes til at være ringere end den dannede befolknings, betonedes det, at alle befolkningsklasser var i fare for "de slette Paavirkninger, som strømmer paa Overfladen og siver ned i Undergrunden". ${ }^{20}$ Sognebogsamlingen var et dige mod denne stadige strøm af dårskab - ikke i kraft af indholdet, men i kraft af de tilknyttede kredses forskellige relationer til bogsamlingen. Det væsentligste var ikke, hvordan bøgerne kom ud til folket, men at de kom ud til folket.

Organiseringen af bibliotekerne var knyttet til en forståelse af læsning og oplysning som en del af den enkeltes private gøremål, og bibliotekerne organiseredes som en forlængelse eller udvidelse af det private område. Med denne forstålse af læsning og oplysning var det på ingen måde nødvendigt at indrette bibliotekslokaler på en særlig måde. Den enkeltes deltagelse - dvs. det private initiativ var fundamentet for bibliotekernes fortsatte eksistens, og ideelt set lå magten hos det enkelte medlem. I realiteten var magten koncentreret hos bestyrelsen med den stærke indflydelse gennem præsten og læreren fra de to væsentligste kontrollerende og disciplinerende institutioner i samfundet: Kirken og skolen. Disciplineringen af befolkningen gennem bogsamlingerne var underordnet de eksisterende disciplineringsformer, hvor religionen var det væsentligste dannelsesmiddel til styrkelse af moral og sædelighed, og hvor skolen underviste $\mathrm{i}$ de færdigheder, der blev anset for nødvendige for at børnene kunne blive nyttige borgere. ${ }^{21}$

\section{Biblioteksvoesenet 1920}

Den samfundsmæssige transformationsproces var karakteriseret ved en organisationsdiskurs med samarbejdet som omdrejningspunkt. Dette var tydeligst inden for arbejdslivet med bøndernes andelsbevægelse, arbejderbevægelsen og arbejdsgivernes organisering. 
Denne forståelse af samarbejdet som det bærende for organisationen kom i stigende grad til at præge bibliotekernes organisering. ${ }^{22}$

$\$ 1$ i Bibliotekstilsynets bekendtgørelse fra 1921 definerede bibliotekets virksomhedsområde på to måder. Dels relaterede virksomhedsområdet sig til den geografiske enhed landsognet, og dels relaterede virksomhedsområdet sig til bibliotekets bogbestand og katalog. For centralbibliotekets vedkommende var amtet (eller et område af tilsvarende størrelse) virksomhedsområdet sammen med en pointering af bogbestandens væsentlighed. ${ }^{23}$ Med den faste geografiske definition af bibliotekets virksomhedsområde begrænsedes antallet af biblioteker, hvilket understregedes af ønsket om at undgå konkurrence mellem de små biblioteker om at få andel $\mathrm{i}$ det statslige tilskud. Begrænsningen blev nøje overvåget $\mathrm{i}$ relation til centralbiblioteket. En første begrænsning var den nødvendige tilknytning til en købstad. En anden begrænsning af antallet var, at undervisningsministeren skulle anerkende et bibliotek som centralbibliotek, medens oplandsbiblioteket (som havde et mindre virksomhedsområde) blot skulle søge om yderligere tilskud og ikke have ministeriel anerkendelse. ${ }^{24}$ Bibliotekets organisationspraksis havde ændret sig fra det selvstændige bibliotek for den lokale kreds til biblioteket som led i en vertikal struktur, der gik fra det mindste bibliotek til det største. Uanset størrelsen for virksomhedsområdet var det enkelte bibliotek led i og udgangspunkt for en hierarkisk opbygget organisation.

Systemet i biblioteksvæenenet blev struktureret fra den mindste enhed til den største: Fra det lokale folkebibliotek (med børnebibliotek) over centralbiblioteket til Statsbiblioteket (og de påtænkte landsbiblioteker) og videre til de videnskabelige biblioteker i København. Den landsdækkende myndighed på folkebiblioteksområdet lå fra 1920 hos Statens Bibliotekstilsyn og Biblioteksrådet, der havde loven som normgivende autoritet. Hvert enkelt led fra det enkelte bibliotek i landsognet og opefter havde nøje definerede og tildelte opgaver. For folkebibliotekets vedkommende blev udbredelsen af skønlitteratur ikke længere anset for at være tilstrækkelig, og biblioteket skulle føres videre frem som arbejdsredskab for hele folket. ${ }^{25}$ Det lille biblioteks kerneområde var håndbogssamlingen, 
hvor det for centralbibliotekets vedkommende var læsestuen og den bibliotekstekniske assistance til bibliotekerne i virksomhedsområdet. ${ }^{26}$ Statsbibliotekets rolle var som overcentral for centralbibliotekerne på landsbasis at sikre den mindre efterspurgte litteratur, selv om denne funktion ikke blev fastlagt $i$ loven af 1920. I et andragende fra 1917 skitseredes en struktur, hvor Statsbibliotekets rolle deltes mellem tre landsbiblioteker, hvoraf Statsbiblioteket var det ene og Københavns Kommunes Biblioteker var det andet. Et tredje foresloges oprettet på Fyn. ${ }^{27}$ Herover kom så de videnskabelige biblioteker i København. Med opgivelsen af denne ide blev de videnskabelige biblioteker i København udgrænset i biblioteksloven med dens tilhørende bekendtgørelser som rent videnskabelige og knapt så folkelige biblioteker.

Dette system var ikke relateret til etableringen af lånevejene mellem de forskellige bibliotekstyper eller til fastlæggelsen af det administrative og økonomiske system mellem det enkelte bibliotek og Bibliotekstilsynet. Det var konstruktionen af biblioteksvæsenet i sin helhed, som rummede de forskellige bibliotekstyper og den landsdækkende myndighed, der udgjorde den hierarkiske organisation.

Med biblioteksloven i 1920 fastsattes den statslige myndighed i Statens Bibliotekstilsyn og Biblioteksrådet, og Statens Bogsamlingskomités administrerende og rådgivende virksomhed deltes $i$ to, således at Biblioteksrådet rådgav ministeren, medens Bibliotekstilsynet fordelte tilskuddene og rådgav bibliotekerne. ${ }^{28}$ Dette skete på baggrund af den stærke centralisering, som i den forudgående periode havde placeret Statens Bogsamlingskomité som det naturlige øverste organ i biblioteksvæsenet. Statens Bogsamlingskomités opgaver var udover fordelingen af tilskuddet rådgivende og tilsynsførende, samtidig med at den sikrede uddannelse af bibliotekarer gennem kurser og udgivelsen af forskellige vejledninger. Ideelt skulle Statens Bogsamlingskomité (eller en tilsvarende statslig instans) desuden fungere som en fælles oplysningscentral, hvortil forespørgsler, som ikke kunne klares på centralbibliotekerne, kunne rettes. ${ }^{29}$ Det centrale mellemled i biblioteksvæsenet var centralbiblioteket, der med den faguddannede bibliotekar byggede bro gennem en rationel ordning af forholdet mellem by og land. 
Biblioteksvæesenet konstrueredes inden for en nøje administrativ praksis, hvor det ene kernepunkt blev bibliotekets vedtægt med fastlæggelsen af styrelsesformen. Sikringen af bibliotekets kontinuitet var fastlagt i denne vedtægt med dens bestemmelse af bestyrelsens sammensætning ved kommunalt eje, tilskud fra amtsråd, og ved foreningseje trådte en række øvrige mekanismer i kraft, således at biblioteket holdtes ude af et for driftigt privat initiativ på foreningens generalforsamling. ${ }^{30}$ Biblioteket situeredes som en offentlig institution, der ikke længere var knyttet til det private område. Som en offentlig institution var det nødvendigt med en helt anden type af kontrol, der inkluderede driften og ikke blot indholdet af biblioteket. Dermed blev et andet kernepunkt i biblioteksvæsenets administrative praksis tilskuddet og ansøgningsproceduren til Statens Bibliotekstilsyn. Derudover etableredes for biblioteket - både folkebiblioteker og centralbiblioteker - en række administrative manøvrer: statistik over udlån på daglig, månedlig og årlig basis, lånerantal, besøg på læsesalen, dagbog over læsesalsbrugen, regnskab og årlig beretning. ${ }^{31}$ Disse forskellige administrative manøvrer medførte behov for en ansvarlig person, der havde en uddannelse $i$ at udføre de forskellige funktioner. Således konstrueredes den faguddannede bibliotekar som en uundgåelig nødvendighed for bibliotekernes videre eksistens. Bibliotekarens magt forankredes i det behov for at kontrollere låneren og bogen gennem de administrative og tekniske procedurer, der opstod som følge af bibliotekets konstruktion som offentlig institution. Magten flyttedes på denne måde fra generalforsamlingen til at blive en del af systemet.

Statstilskuddet blev nøje defineret i relation til bestemte parametre og gradueret i forhold til disses betydning og værdi. Alle biblioteker kunne søge om tilskud til drift og oprettelse, og allerede oprettede biblioteker kunne fă tilskud til en reorganisation, som vedrørte den indre organisation: bogbestanden og dens klassifikation og katalogisering samt oprettelse af læesestue med håndbogsamling. ${ }^{32}$ Tilskuddene medførte en skarp sondring mellem bibliotekerne, således at det moderne folkebibliotek skabtes gennem brugen af de særlige tilskud, der blev ydet ved drift af læsestue og håndbogsamling samt ved etablering af gratis udlån og ansættelse af en uddan- 
net bibliotekar. $\$ 3$ i ministeriets bekendtgørelse omhandlede bogbestandens sammensætning, der skulle inkludere oplysende litteratur ud fra et krav om alsidighed. På denne vis artikulerede bekendtgørelsen den bagvedliggende forudsætning, at der ikke skulle ydes tilskud til biblioteker, der kun udlånte underholdende litteratur, hvorved billedet af sogne- eller folkebogsamlingen som gammeldags og umoderne skabtes. ${ }^{33}$ Forholdet mellem biblioteket og det statslige tilskud var betinget af de stedlige tilskud. Her skelnedes stærkt mellem faste og enkeltstående tilskud. De faste tilskud kom fra lokale autoriteter som kommunen, lokale institutioner som sparekasser og fra privatpersoner. Endelig kunne faste stedlige tilskud komme fra den lokale biblioteksforening, hvis en sådan eksisterede. Men kun på bestemte betingelser, da medlemmernes kontingent kun kunne betragtes som tilskud, hvis det ikke gav dem forret til lån af bøger fra biblioteket. En biblioteksforening, hvor medlemmernes kontingent var betaling for at fầ bøgerne først i en cirkulationslæsekreds, inden de overgik til biblioteket, var ikke længere acceptabel. ${ }^{34}$

Lånerens og bibliotekarens forhold til biblioteket defineredes nøje i loven samt dens bekendtgørelser og i de forslag til instrukser for bibliotekaren, som var tilknyttet bekendtgørelserne. For bibliotekarens vedkommende var instruksen naturligvis af stor væsentlighed, da normerne for den gode bibliotekar her fik en tydelig udformning gennem beskrivelsen af rammerne for bibliotekarens arbejde, forventningerne til bibliotekaren og ved i realiteten at beskrive den daglige drift af biblioteket. ${ }^{35}$ Bibliotekaren blev set som det første led i systemet, og hans opgaver var i forhold til biblioteket og ikke $\mathrm{i}$ forhold til bogen eller låneren, der begge som uorganiserede dele skulle disciplineres gennem og indordnes under bibliotekets administrative praksis. Til dette formål anvendtes en række systemer til klassedeling og katalogisering af bøgerne, medens lånerne indordnedes gennem etableringen af udlånssystem og faste åbningstider for biblioteket i almindelighed og læsestuen i særdeleshed. ${ }^{36}$ Den administrative praksis til håndtering af bøgerne medførte en reduktion af litteraturens indholdsmæssige og oplysningsmæssige værdi til fordel for bogen som et objekt og nummer 
i de forskellige systemer og statistikker. Lånerne var nødvendige statister i bibliotekarens faglige selvforståelse, da kun bibliotekaren $\mathrm{i}$ kraft af sin uddannelse kunne give lånerne de oplysninger, som de måtte formodes at søge. Hverken bogen eller låneren var i sig selv centrale for det moderne folkebibliotek, og de opnåede kun betydning ved at træde $\mathrm{i}$ forbindelse med bibliotekaren og dennes administrative praksis.

Den væsentligste administrative praksis, som omfattede bogen i forbindelse med biblioteket, var definitionen af den litteratur, der burde findes på biblioteket. Grundlaget for denne administrative praksis koncentreredes i bibliotekslovens formulering: "Grundtilskud ydes til Biblioteker, hvis Opgave er at udbrede Kundskaber og almindelig Oplysning." ${ }^{37}$ Hvad der blev forstået under almindelig oplysning uddybedes i $\$ 3$ i ministeriets bekendtgørelse, hvoraf det fremgik, at bogbestanden skulle være alsidigt sammensat og bestå af oplysende litteratur inden for en række emner (teologi, naturkundskab, de praktiske erhverv og litteratur af samfundsmæssig karakter etc.). Desuden skulle bogbestanden rumme skønlitterære værker, hvor kvalitetskravet defineredes som "... det bedste af den danske Litteraturs Frembringelser." ${ }^{38}$ Befolkningens læselyst, læsetrang og læseevne skulle udnyttes i "... Erhvervslivets og den virksomme Folkeopdragelses Tjeneste ..." ${ }^{\prime 39}$ - ikke i en gold og ufrugtbar fornøjelseslæsning.

Det moderne folkebibliotek skulle være et laboratorium for studier med henblik på at møde det praktiske livs udfordringer, og det væsentligste aspekt $\mathrm{i}$ dette laboratoriearbejde var vejledningen udøvet af bibliotekaren over for låneren. ${ }^{40}$ I vejledningen smeltede den administrative praksis sammen med låneren og bogen til det kerneelement, der skulle bringe oplysningen ud blandt befolkningen. Vejledningen kunne simpelthen ikke undværes i det moderne folkebibliotek. Organisationen og vejledningen var måden, hvorpå oplysningen skulle udbredes. Den betydning, som de administrative manøvrer for organisationen og vejledningen blev tillagt, medførte, at det ikke var udbredelsen af oplysningen, der var det væsentligste, men derimod måden for udbredelsen. Magten flyttede ind $\mathrm{i}$ systemet med dets administrative manøvrer, der disciplinerede 
bibliotekaren til at agere på en bestemt vis. Det moderne folkebibliotek indtog en disciplinerende funktion over for befolkningen som helhed gennem introduktionen af den bestemte forståelse af læsning og oplysning, som blev udtrykt gennem bibliotekarens rolle samt gennem placeringen og indretningen af biblioteket.

Biblioteket $i$ byens rum

Bibliotekets fysiske placering og indretning blev i stigende grad en del af disciplineringen af befolkningen. Hverken placering eller indretning blev foretaget efter tilfældige principper, men underlagt en række overvejelser, som kom fra centralt hold fra Statens Bogsamlingskomité og senere fra Statens Bibliotekstilsyn.

Bibliotekerne blev med inspiration fra USA forstået som et byfænomen, og selv på landet lå bibliotekerne i byen. ${ }^{41}$ De fleste landsbyer kunne størrelsesmæssigt ikke konkurrere med hverken stationsbyer eller købstæder, men var ikke desto mindre den bymæssige bebyggelse i sognet. For at skabe biblioteket som et bøgernes hjem var det nødvendigt med et særligt afgrænset område, der var kendetegnet ved brugen af bøger eller gennem opbevaringen af bøgerne. Det hjem, der oftest skabtes for biblioteket, lå enten i skolen eller i forsamlingshuset. Skolen var især yndet, hvis skolestuen ikke var for fugtig. Som afgrænsning til de øvrige aktiviteter, der fandt sted, var biblioteket angivet ved skabene (helst aflåselige) til opbevaring af bøgerne..$^{42}$ Det centrale var netop opbevaringen af bøgerne, og selv om et særligt lokale var ønskeligt, var det ikke påkrævet. Også private hjem kunne rumme bogskabene, selv om det ikke var tilrådeligt. ${ }^{43}$ Biblioteket var i det ydre umærket og i sit indre sammenblandet med andre aktiviteter (skolen, forsamlingshuset eller privatlivet), hvilket kolliderede med en ændret opfattelse af biblioteket som det neutrale sted for bogopbevaring. Skolen eller forsamlingshuset blev ofte betragtet som neutrale opbevaringssteder ${ }^{44}$ For større forhold i byerne og i København var et særligt lokale nødvendigt, men i sammenligning med forholdene $\mathrm{i}$ USA og England (hvor sidstnævnte var det bedst kendte sammenligningsgrundlag) blegnede de størrelsesmæssigt, udstyrsmæssigt og i praktisk henseende. ${ }^{45}$ Biblioteket var ikke blot et hjem for bøger- 
ne; det skulle indrettes hjemligt for at sikre en hyggelig stemning som kunne virke tiltrækkende på brugerne, og samtidig disciplinerede denne hyggelige og rolige stemning især utilpassede elementer (som de unge) til at betragte biblioteket som et reelt alternativ til unyttige fornøjelser som kortspil og lignende. ${ }^{46}$ Indretningen af læsestuerne og især børnenes blev foretaget efter denne devise med lænestole, planter og udsmykning af forskellig art. Hvor biblioteket altså beliggenhedsmæssigt skulle have et offentligt præg og ikke forbindes med det private hjem, måtte det udstyrsmæssigt gerne ligne det. Gennem placeringen af biblioteket og dets indretning situeredes det som en institution på grænsen mellem det private område og det offentlige.

\section{Det sarlige lokale}

Fra afgrænsningen gennem anvendelsen af særlige skabe var der ikke langt til en afgrænsning af bibliotekets rum gennem et særligt lokale eller endda gennem en særlig bygning. Larebog i Biblioteksteknik (1922) er særdeles eksplicit i, hvilke krav der skulle stilles til et bibliotekslokale (forstået både som lokalet og som bygningen), for at det kunne markere denne afgrænsning. Ved udvælgelsen af dette særlige lokale (hvad enten det nu blot var et lokale eller flere lokaler $\mathrm{i}$ en anden bygning eller en selvstændig bygning) måtte hensynet til benyttelsen gå frem for alt. En anden væsentlig faktor ved lokalevalg var beliggenheden. Af hensyn til læsesalen måtte der være tale om et centralt beliggende sted $\mathrm{i}$ byen, og desuden måtte det være bekvemt - dvs. let tilgængeligt - helst stueetage eller første sal. En adskillelse indtrådte her mellem det særlige lokale og den selvstændige bygning. En selvstændig bygning ville i kraft af sin egen eksistens og størrelse være centralt beliggende og synlig, medens det særlige lokale kunne være involveret $\mathrm{i}$ en anden sammenhæng. Det var vigtigt, at bibliotekets lokaler lå $\mathrm{i}$ en offentlig bygning og ikke kunne forbindes med en snæver forening. Beliggenhedens betydning understregedes af, at et centralt beliggende bibliotek ville blive brugt væsentligt mere end et bibliotek med en perifer eller ulogisk placering i byen. At skaffe biblioteket et selvstændigt hjem var ikke et statsligt foretagende, men overladt til de lokale kræfter og 
myndigheder trods forslag om at sørge for biblioteksbygninger på landet. ${ }^{47}$

De overordnede krav til det særlige lokale medførte en yderligere afgrænsning i forhold til mulige lokaler, som kunne stå til rådighed for et bibliotek i byen. Lokalerne skulle være lyse og rummelige, og her var ventilationen og belysningen væsentlige (deres betydning behandles senere). Dette medførte en afgrænsning i forhold til mørke og triste lokaler, som ikke ville virke befordrende for publikums lyst til at bruge biblioteket. Sådanne lokaler måtte under ingen omstændigheder accepteres, selv om de blev overdraget biblioteket som gave. Rummeligheden af lokalet relateredes til muligheden for ændringer af rummet og for en fleksibel indretning af rummet. For biblioteker i et rum kunne indretningen tage form af et $T$, medens biblioteker i flere rum indrettedes efter den såkaldte sommerfugletype. Men indretningen var betinget af lokalernes form, og selv en umulig form som en hjørnebygning kunne give gode muligheder for den mest hensigtsmæssige indretning. ${ }^{48}$ Selve indretningen blev på denne måde underkastet en række betingelser, hvoraf hensynet til den daglige brug var den mest fremtrædende, og en indretning, som efterlevede dette, ville altid krones med at være hensigtsmæssig og praktisk.

Bibliotekets rum blev afgrænset som bøgernes hjem over for kirken, skolen og evt. forsamlingshuset, der var andre tydelige rum $\mathrm{i}$ byen, og som havde hver deres bestemte funktioner. Fra den mere utydelige markering af biblioteket gennem anvendelsen af bogskabe, blev biblioteket aftegnet gennem en selvstændig bygning eller et selvstændigt lokale. Derigennem understregedes det væsentlige $\mathrm{i}$ at placere biblioteket som en offentlig institution, der kun i overført betydning var forbundet med det private hjem gennem indretningen. Forbindelsen til det private blev desuden kappet ved at fremhæve bibliotekets relationer udadtil gennem et tilknyttet museum eller en foredragssal i den ideelle biblioteksbygning. ${ }^{49}$ Bibliotekets placering var, om ikke en videnskab, så dog et område, som stillede særlige krav. Dette understregedes af, at det blev betragtet som rimeligt at afvise et lokale som gave ud fra kravet om at kunne etablere et tidssvarende bibliotekslokale. Med den fysiske afgrænsning 
af bibliotekets rum skabtes ligeledes en mulighed for at afvise andre biblioteksmæssige tilbud. Dette kom tydeligst frem i relation til den selvstændige biblioteksbygning, som qua sin egen eksistens skabte interesse og kendskab blandt byens befolkning og på denne vis ledte den hen til biblioteket, når der skulle lånes bøger. På denne måde disciplineredes befolkningen til kun at søge ét sted, når der skulle lånes bøger eller fremskaffes oplysninger. Denne disciplinering fortsatte gennem indretningen af bibliotekets lokaler, og herigennem disciplineredes befolkningen til at fungere som lånere, samtidig med at der skabtes et behov for en overvågende og kontrollerende instans: bibliotekaren.

\section{Biblioteksrummet}

På grundtegningen af Centralbiblioteket i Næstved ses sommerfugletypen som indretningsmodel. Den centrale midte var optaget af udlånet, hvortil var knyttet en forhal, garderobe, toiletter og et rum til telefon. Skranken var placeret mod den forreste væg med indgangsdør til udlånet på den ene side og udgangsdør på den anden. Dette gav en god færdselsregulering og kontrol med en fortræffelig oversigt over biblioteket. ${ }^{50} \mathrm{I}$ vingerne placeredes læsesalene og kontorer samt nedgang til bogmagasinet. Der var en særlig læsesal til børnene og en til de voksne med stort set ens indretning. Gennem denne grundplan ses tre-delingen af bibliotekets kerneområder: Udlånet, læsesalen (med håndbibliotek) og det indre bibliotekariske arbejde, som primært fandt sted i kontorerne. Den tydelige fysiske opdeling virkede regulerende både for lånerne og for bibliotekarerne, hvor de enkelte handlinger, som et biblioteksbesøg bestod $\mathrm{i}$ for låneren, blev fordelt på forskellige lokaler. Sommerfugletypen betegnede bibliotekets tre funktioner særdeles eksplicit, men de kunne let rummes i biblioteker, der kun havde ét rum til deres rådighed. Kerneområderne for biblioteket var uafhængige af, om biblioteket havde en selvstændig bygning, flere lokaler eller blot et enkelt lokale. I små biblioteker blev bibliotekarens kontor reduceret enten til skranken i udlånsområdet eller ved endnu mindre forhold til bibliotekarens skrivebord. I begge tilfælde smeltede det bibliotekariske indre arbejde sammen med det ydre. 


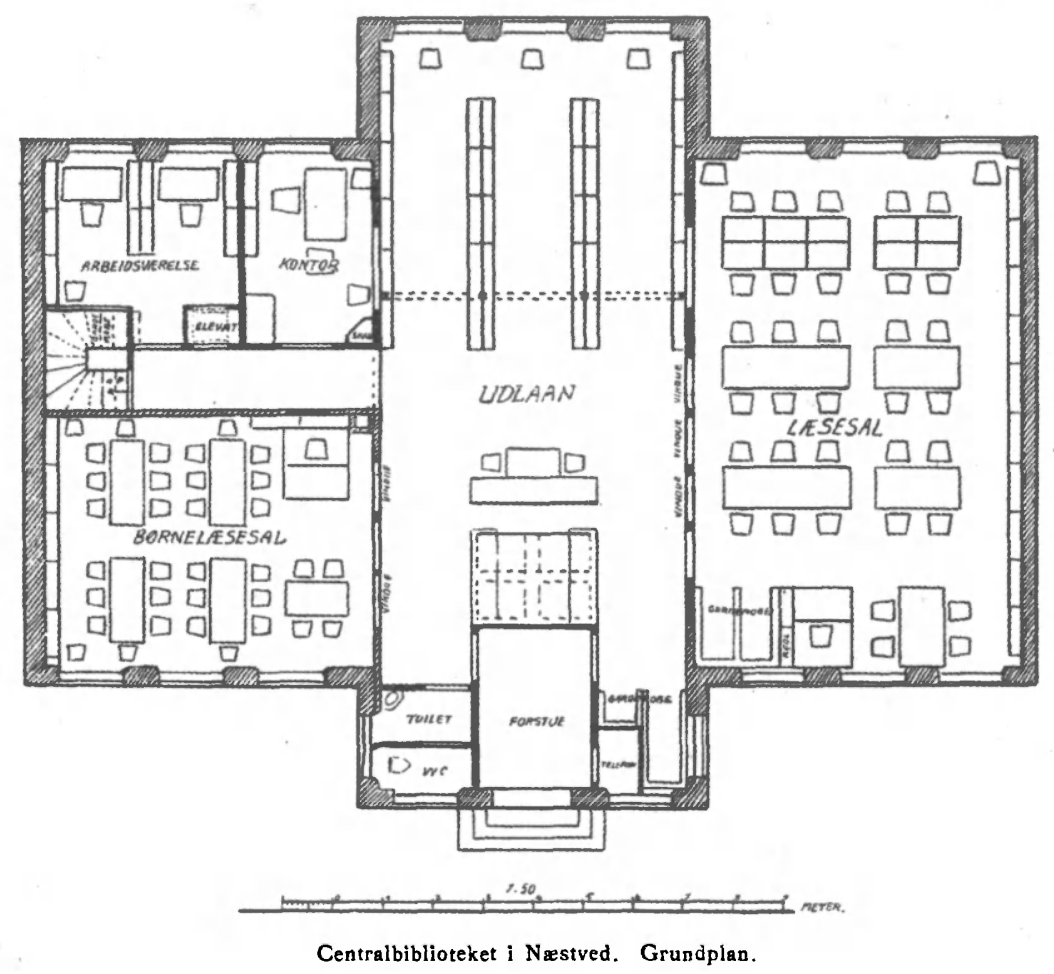

Grundtegning af Centralbiblioteket $i$ Nestved. Her prosenteredes den populare sommerfugletype, der anvendtes i flere efterfolgende biblioteksbyggerier, da dens rumudnyttelse betragtedes som optimal. (Fra Larebog i Biblioteksteknik, 1922, s. 149)

En lignende eksplicit opdeling af bibliotekets virkeområde sås i Biblioteket for Vejle Amt og By, inden det endnu var blevet etableret som forsøgs-centralbibliotek. Her fandtes også tre afdelinger: (1) læsesalen, (2) den videnskabelige afdeling, og (3) afdelingen for folkelæsning. Opdelingen her rettede sig kun mod det ydre arbejde gennem udlån og læsestue med en gradsforskel i udlånsbogsamlingen mellem det videnskabelige og folkelæsningen. Men den var i overensstemmelse med indretningen af arbejdsområder, medens en opdeling af biblioteket $\mathrm{i}$ afdelinger, der afspejlede lånernes sociale stilling, ikke kunne accepteres. ${ }^{51}$ 
Grundplanen for Centralbiblioteket i Næstved var udkrystalliseringen af den fordeling, som skabte afgrænsede rum i selve biblioteket. Fordelingen opererede gennem fem former for typologisering, hvorved de afgrænsede rum tilkendtes hver deres funktion: Det organiske og sammenhængende; værkstedet; udbredelsen; kontrollen; sundhed og opdragelse. Det organiske og sammenhængende definerede biblioteket som en enhed bestående både af udlån, læsesal og det bibliotekariske arbejde. Biblioteket skulle give adgang både til læsestuen og til udlånet, og det blev betragtet som uhensigtsmæssigt, om udlån og læsestue lå forskellige steder. Selv i Vejen, hvor der i forvejen var et udlånsbibliotek, blev det mæcen-finansierede bibliotek udover læsestue med tilknyttet håndbibliotek udstyret med et mindre udlånsbibliotek, hvis virksomhed kunne udvides om nødvendigt. ${ }^{52}$ Blandt de tre virksomhedsområder var det organiske især til stede $\mathrm{i}$ relationen mellem udlånet og læsesalen. Læsesalen var en organisk del af biblioteket med nær forbindelse til både udlånssamlingen og bogmagasinet. På tilsvarende vis var de åbne hylder på læsesalen en del af udlånsbogsamlingen, og alle bibliotekets bøger var i umiddelbar nærhed af publikum, hvilket cementerede bibliotekets betydning i byens rum som det sted, befolkningen skulle henvende sig med henblik på at låne eller læse litteratur.

\section{Vicrkstedet}

Den organiske sammenfletning af de to væentlige rum i biblioteket betød ikke, at der var flydende grænser mellem de funktioner, som udlånet og læsesalen blev tilkendt. De blev tværtimod trukket uhyre skarpt op gennem forskellen mellem værkstedet og udbredelsen som arbejdsmåder. Værkstedets udformning var defineret gennem opstilling af borde, stole og evt. læsepulte til aviserne med en nøjagtig udregning af antallet af kvadratmeter pr. læser, en placering af bibliotekarens bord, og af at der skulle sikres plads til redskaberne i værkstedet $\mathrm{i}$ form af håndbogsamlingen..$^{53}$

Placeringen af læsepladserne var betinget af bibliotekarens mulighed for at overvåge de læsende. ${ }^{54}$ Hvilken bordtype, der blev anset for den mest hensigtsmæssige, varierede over tid. Runde borde havde den fordel, at de $\mathrm{i}$ almindelighed gav et bedre overblik over 
de læsende, da der ikke ville være mulighed for at sidde med ryggen til bibliotekaren, og kunne anvendes med fordel, hvor det ikke var muligt at vende bordene mod bibliotekaren, men de krævede mere plads i rummet og gav mindre plads til den læsende..$^{55}$ Hvis det var nødvendigt, f. eks. hvis der var adskillelser mellem læsepladserne, kunne bibliotekarens bord anbringes på et podium af hensyn til det bedre overblik. ${ }^{56}$

Afgrænsningen til udlånet udførtes desuden gennem fastlæggelsen af en bestemt materialetype, der befandt sig på læsesalen: håndbiblioteket, tidsskrifter og aviser, og deres funktion som redskaber betingedes af, at de kun kunne bruges på læsesalen. Som laboratorium og værksted var læsesalen afhængig af, at publikum stillede spørgsmål, der skulle besvares enten ved direkte at konsultere håndbiblioteket og bibliotekaren eller gennem mere dybtgående studier. Læsesalen fungerede ikke uafhængigt af håndbiblioteket, som nærmest var at betragte som forudsætningen for en læsesal. Håndbogssamlingen var det ypperste kulturmiddel og kun herigennem kunne læsesalen fungere som et kraftuddrag af biblioteket. Et godt håndbibliotek var sammensat som den bogsamling, man ville finde hos "en gennemdannet og velhavende Privatmand". ${ }^{77}$ I sin kerne bestod det af et konversationsleksikon, ordbøger, historiske værker, lovsamlinger og andre håndbøger i retning af samfundskundskab samt tekniske og naturvidenskabelige håndbøger. ${ }^{58}$ Idealet for håndbiblioteket var inspireret af den borgerlige dannelse, der var forankret i troen på den menneskelige fornuft og evnen til refleksion over det læste. Som en følge af denne tiltro til fornuften og refleksionsevnen var der ikke behov for en begrænsning af udbuddet i materialetyperne, og hverken læsesal eller håndbibliotek måtte være udtryk for ensidig påvirkning af de læsende. Kernen i bibliotekets arbejde forankredes $i$ en forståelse af neutralitet, der udmøntedes $i$ bibliotekets placering $i$ byen og $i$ sammensætningen af henholdsvis håndbiblioteket, tidsskrifterne og aviserne på læsesalen. Derfor afvistes den neutralitetsforståelse, som blev praktiseret på København Kommunes Biblioteker i 1880'erne med udelukkelse af aviser på læsesalen, som utilstedelig, da den stred mod tiltroen til den menneskelige fornufts evne til kritisk refleksion. Neutraliteten blev en 
implicit kontrolmekanisme, der - som en generel accept af aviser repræsenterende alle politiske partiorganer på læsesalen - disciplinerede læserne til at agere som udtryk for det borgerlige menneske.

For at understrege funktionen af værksted eller laboratorium indførtes en stilhedsklausul, som kunne diktere en yderligere inddeling og opdeling af læsesalen i flere afgrænsede rum: for voksne, for børn, for tidsskriftlæsning og for avislæsning. Læsesalen skulle ikke fungere som en varmestue, hvor befolkningen kun søgte aviserne som tidsfordriv, og desuden betragtedes avislæsning som særligt støjende. Hvis der ikke etableredes en særlig avislæsesal, skulle avislæsningen foregå tættest ved udgangen fra læsesalen og helst ved pulte. Ved i stadigt højere grad at inddrage avislæsningen i selve læsesalen defineredes avislæsningen som en mere lødig beskæftigelse med karakter af at holde sig oplyst om de væsentlige begivenheder i samfundet. ${ }^{59}$ En anden opdeling af læsesalen var efter graden af brugen. Elementær læsning og opslag i håndbøgerne hørte hjemme i selve læsesalen, medens der kunne indrettes særlige studieværelser til videregående studier. Børn burde på ingen måde have adgang til den almindelige læsesal eller til voksenudlånet, da de stillede særlige krav ved brugen af biblioteket. Deres larmende opførsel nødvendiggjorde etableringen af en afgrænset læsesal, ligesom deres endnu ikke udviklede fatteevne medførte behovet for at hindre dem $i$ at fă adgang til voksenbøger og således beskytte dem mod en læsning, der gik ud over deres evner.

Gennem kyndig vejledning (fra en bibliotekar) fungerede læsesalen som et oplysningsbureau og en omstillingscentral, hvor forespørgsler blev stillet videre til de rigtige svar, og hvorfra publikum gik bort i ændret tilstand - mere oplyste og vidende end da de kom. Omstillingsprocessen krævede en dialog, som fandt sit eksplicitte udtryk i begyndelsen af århundredet i samtaleværelser (med evt. servering), men indsnævredes til kun at kunne komme til udtryk $i$ læserens dialog med bibliotekaren gennem vejledningen. Konversationsstuerne mistede deres betydning og kom i direkte modstrid med bibliotekarens faglige ståsted og påbuddet om stilhed på læsesalene. ${ }^{60}$ Laboratoriet og værkstedet inddrog ikke kun hånd- 


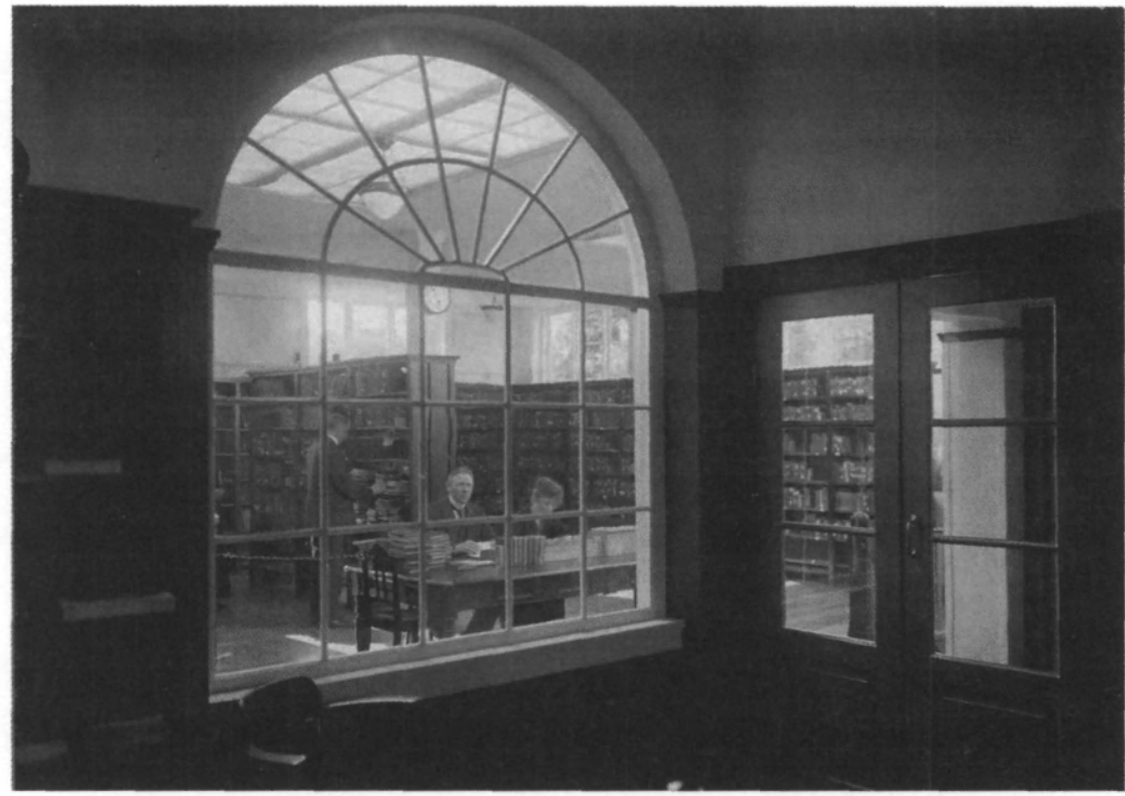

Opsynet med lasesalen skulle ikke nodvendigvis vare til stede på lasesalen. Gennem vinduer kunne bibliotekaren fra skranken holde oje med de losende på losesalen, og disse kunne hengive sig til deres studier uden forstyrrelser fra udlanet. Da der var en udbredt mangel på personale og midler til samme, var konstruktionen med glasvinduer en glimrende losning. Billedet er fra Svendborg By og Amts Bibliotek. (Danmarks Biblioteksskole. Bibliotekshistorisk Samling)

bøger og belærende læsning, da læsesalen i kraft af sin organiske forbindelse til udlånsbiblioteket også kunne rumme underholdende læsning.

Læsesalen rummede både kundskabsbøger og delvist bøger til hjemlån. En konkurrerende tendens til læsesalen som værksted og laboratorium var læsesalens funktion som et andet hjem. I lyse og hyggelige lokaler med lænestole indbød læsesal, håndbibliotek og underholdende læsning til fordybelse i skarp konkurrence med hjemmet. Dette blev delvist begrædt, men fra flere sider blev nødvendigheden af dette neutrale hjem i stigende grad erkendt som en løsning på de sociale problemer, som blev forbundet med ungdommen. ${ }^{61}$ 


\section{Udbredelsen}

Fællesnævneren for både læsesalen og udlånet var den direkte (og uhindrede) adgang til bøgerne, men hvor læsesalen bestemtes til brug på stedet, var udlånet eller hjemlånet en udadvendt aktivitet, der defineredes gennem udbredelsen af bøger til omegnen. Udlånet var en lige så selvstændig funktion i biblioteket som læsesalen og krævede sit eget lokale. For ikke at forstyrre roen på læsesalen var der ikke mulighed for at have adgang til udlånet gennem læsesalen, og udlånet kunne ikke foregå gennem en dør eller luge fra læsesalen. Dette ville desuden hindre den direkte vejledning af låneren. Udlånet var ikke underkastet stilhedsklausulen fra læsesalen, hvilket betød en skarp sondring mellem de to funktioner i biblioteket. I udlånet kunne lånerne bevæge sig frit i forhold til opslag i katalogen og siden hen blandt de åbne hylder. Som læsesalen var udlånet defineret gennem dialogen mellem bibliotekar og låner udmøntet $\mathrm{i}$ vejledningen ved udvælgelsen af bøger, og alene af den grund var det nødvendigt med et afgrænset rum til denne dialog. De øvrige processer i udlånet (såsom aflevering og udnotering af bøger) krævede en helt anden form for fysisk mobilitet, som ikke kunne forenes med læsesalens stilhedsklausul.

Den reelle selvstændiggørelse af udlånet indtrådte med ideen om de åbne hylder. Alene pladsforbruget til disse gjorde dem uforenelige med bibliotekarens overvågning af de læsende i læsesalen, og kontrollen med dem identificeredes som værende af en særlig karakter. Ăbne hylder forbandtes også med opstillingen af håndbiblioteket i læsesalen, men omfanget deraf var langt mindre end i forbindelse med udlånet og var desuden underkastet bibliotekarens overvågning på læsesalen.

Kontrollen med bøgerne og adgangen til dem havde i de små bogsamlinger rundt om i landet været særdeles fysisk og direkte markeret gennem (lukkede) bogskabe, hvortil som regel kun bibliotekaren havde adgang. Âbne hylder betragtedes i denne optik som reelt problematiske, da de var ubevogtede. ${ }^{62}$ Samtidig garanterede skabene den vigtige dialog mellem bibliotekar og låner gennem vejledningen, når låneren henvendte sig til bibliotekaren med sin ønskeseddel, dvs. en bestillingsliste over de bøger som låneren øn- 
skede. Sådan skabtes en effektiv kontrol fra bibliotekarens side med henblik på at kunne afvise begæringer om uønsket litteratur. ${ }^{63}$ Forskellen mellem de 'gammeldags' (lukkede) bogskabe og de anglo-amerikansk inspirerede åbne hylder synes ganske åbenlys og ligetil: De åbne hylder lanceredes herhjemme ud fra princippet om netop åbenheden og den direkte adgang. De åbne hylder havde deres sidestykke $\mathrm{i}$ åbne døre, og sammen garanterede de bibliotekets trivsel, da lånerne selv kunne komme til hylderne og $\mathrm{i}$ fred, ro og frihed kunne udvælge de bøger, som de ville have med hjem. Samtidig tilkendtes de åbne hylder en substantiel opdragende betydning, da lånerne gennem den frie adgang til hylderne lærte at omgås bøgerne og indøve brugen af dem som en god vane. Det var lånerens ønske, der blev sat i centrum for bibliotekets virksomhed.

Netop lånernes mulighed for selv at kunne vælge bøgerne direkte fra hylden var udgangspunkt for den kritik, der kom til orde ved biblioteksmødet i Ârhus i 1909. Det blev fremholdt, at de åbne hylder underminerede bibliotekarens vejledning af låneren, og at de kørte bibliotekaren ud på et sidespor. En understregning af sidesporet fremhævedes ved påpegningen af den uorden, der ville komme til at herske blandt bøgerne på hylderne med den konsekvens, at bibliotekaren ikke ville kunne finde bøgerne. Og kernen i bibliotekarens selvforståelse var forankret $\mathrm{i}$ at kunne finde den rigtige bog til låneren. Ligeledes konstateredes det, at katalogen ville miste sin status med tilsvarende konsekvenser for den bibliotekariske faglige selvforståelse, der var fast forankret i skabelsen af overskuelighed gennem katalogen. Kontakten til England gav imidlertid erfaringsmæssigt grundlag for, at det rådgivende forhold mellem bibliotekar og låner ikke ville gå tabt ved brugen af de åbne hylder. ${ }^{64}$

Argumenterne for de åbne hylders indførelse understøttedes af en række økonomiske betragtninger, da de åbne hylder medførte en eksponering af de gamle og sjældent udlånte bøger. Gennem eksponeringen på de åbne hylder ville flere af de gamle bøger blive lånt ud og afhjælpe den dårlige udnyttelse af bibliotekernes bøger. ${ }^{65}$ Samtidig var der en rationaliseringsgevinst ved, at bibliotekaren ikke længere behøvede at finde bøgerne frem i de lukkede skabe (eller i bogmagasinet i de store biblioteker), hvilket gjorde ekspeditionen 
billigere. Senere påpegedes det, at dette argument ikke holdt stik, da der under alle omstændigheder skulle være en bibliotekar i udlånet. Det største problem ved indførelsen af de åbne hylder syntes at have ligget i de rent fysiske forhold. En opstilling på åbne hylder krævede et langt større lokale, end de fleste biblioteker havde til deres rådighed: Lånerne kunne ikke bydes selv at skulle kravle til vejrs på stiger for at hente bøger ned, hvorfor reolernes højde måtte sættes ned i forhold til eksempelvis reolerne i magasinet. Reolernes højde havde desuden betydning for bibliotekarens mulighed for at overskue hele udlånslokalet, så også af den grund var for høje reoler uhensigtsmæssige. Af hensyn til bevægeligheden skulle der være en bestemt afstand mellem reolerne, hvilket kunne være uforeneligt med størrelsen af det lokale, som var til rådighed for det enkelte bibliotek. For lettere at kunne beregne lokalets størrelse i forhold til bøgerne gaves nøje beregninger over, hvor mange bind der kunne være på en kvadratmeter, hvor brede hylderne kunne være etc. ${ }^{66}$

De åbne hylder betød ikke kun frihed for lånerne og en opgivelse af kontrollen med lånerne. I sammenligning med de lukkede skabe betonedes det, at der var tale om en særlig form for kontrol både ved hylderne og ved udgangen. Kontrollen fik form af en langt mere bevægelig bibliotekar, der skulle befinde sig i udlånsområdet, samt af skranken (disken), som sikrede, at alle lånerne passerede en bibliotekar eller assistent på vej ud af biblioteket, og endelig gennem et langt mere finmasket udnoteringssystem, end der tidligere havde været $\mathrm{i}$ brug. Brugen af de åbne hylder medførte, at behovet for kontrol i langt højere grad knyttedes til bogen som genstand frem for til bogens indhold og oplysningsmæssige værdi.

Indretningen af bibliotekslokalet til brug af åbne hylder understregede, at behovet for kontrol stadig fandtes. Den optimale opstilling af reolerne var den såkaldte stråleform. Her udgik reolerne i en halvcirkel fra bibliotekarens plads (eller fra skranken) med det bedst mulige udsyn for bibliotekaren. Der var forbundet et vist fysisk problem med denne optimale opstilling, da pladsen omkring udlånets centrale kerne, bibliotekarens plads, blev kraftigt indsnævret. En varierende opstilling af reolerne i parallelle rækker ud fra skranken var derfor acceptabel og blev blandt andet anvendt på Centralbiblio- 
Opstillingen i stråleform blev vurderet som den mest optimale, men problematisk $i$ praksis. I grundplanen for Svendborg By og Amts Bibliotek opstilledes reolerne $i$ stråleform, medens de tilsyneladende i praksis opstilledes som på grundplanen for Nestved Centralbibliotek. (Tegningen er fra Larebog i Biblioteksteknik, 1922, s. 135)

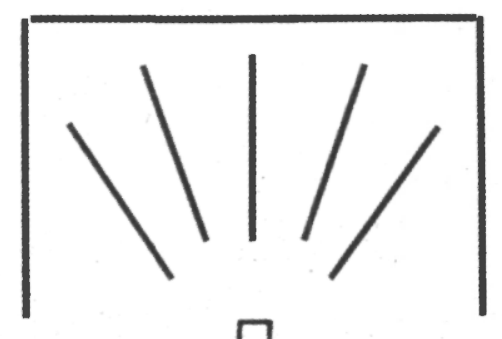

teket i Næstved. Kontrollen ændredes fra lånerens henvendelse til bibliotekaren til bibliotekarens henvendelse til låneren samt i en mindre synliggørelse gennem den administrative praksis ved skranken. De åbne hylder betød en væsentlig styrkelse af bibliotekarens centrale position $\mathrm{i}$ bibliotekssystemet, da vejledningen af låneren ikke længere blot kunne indskrænkes til at afslå udlån af en bestemt bog. Med de åbne hylder måtte bibliotekaren sandsynliggøre over for låneren, at den ønskede bog vitterlig var ubrugelig for netop den pågældende låner. De saglige argumenter kunne bibliotekaren i stigende grad hente i sin faglige uddannelse, der påbød et bredt kendskab til bøgerne i biblioteket.

\section{Kontrollen}

Skranken (og bibliotekarens plads) blev betragtet som udlånets centrum. Placeringen af den i udlånslokalet var tættest ved indgangen til og udgangen fra biblioteket, således at den indadgående strøm gik den ene vej om skranken, medens den udadgående strøm blev ledet forbi skranken. ${ }^{67}$ Lånerne disciplineredes til en korrekt adfærd ved ankomsten til og afgangen fra biblioteket via skrankens placering, medens bibliotekaren disciplineredes i sine arbejdsrutiner gennem indretningen af skranken. ${ }^{68}$ Skrankens højde var iøjnefaldende, da den skulle sikre en komfortabel arbejdsstilling for den stående bibliotekar. En skammel kunne være en nødvendighed, men skulle ikke bruges i overvældende grad. Skrankens centrale indhold var 'vasken' til bogkort over de udlånte bøger ordnet efter dato med henblik på hjemkaldelse. Desuden rummede den lånerfortegnelsen, der var i form af et kortkatalog. I bordpladen fandtes derudover tre 
aflange huller (tilpasset bogkortenes størrelse), så at der kunne foretages en grovsortering af de udlånte bøger - formodentlig efter status af børnebøger, skønlitteratur og faglitteratur til brug for den daglige statistik over udlånets omfang og art. Skrankens korrekte indretning var af stor betydning for den økonomiske drift af biblioteket: alt havde faste pladser og var lige ved hånden, så at alt vedrørende udlånet kunne ordnes fra et sted i udlånslokalet. Hvis biblioteket havde en vis størrelse var det nødvendigt med særskilte lokaler til det bibliotekariske arbejde, ellers kunne skranken gøre det ud for disse. Bibliotekaren burde - selv i små biblioteker - have sit eget kontor, der skulle indeholde et jernpengeskab til væentlige dokumenter (tilvækstprotokollen) og være placeret tæt ved hovedindgangen. Kontorlokalerne skulle være rummelige og være placeret $\mathrm{i}$ nærheden af udlånet og håndbogssamlingen. Ärsagen til det sidstnævnte var, at håndbiblioteket anvendtes ved katalogiseringsarbejdet. Men selve arbejdet med bøgerne burde ikke foregå i de offentligt tilgængelige lokaler, da det derved ville fâ et uøkonomisk skær.

Skrankens placering var dikteret af behovet for en nem og hurtig oversigt over både de åbne hylder og læsesalen. Dette var en yderligere rationaliseringsgevinst især for små biblioteker, hvor det kunne være forbundet med store økonomiske vanskeligheder at have to bibliotekarer ansat til varetagelse af de to funktioner. Oversigten over de åbne hylder var som næunt understøttet af den særlige opstillingsform for reolerne, medens tilsynet med læsesalen var betinget af enten en glasvæg ind til læsesalen eller som minimum, at der kunne holdes opsyn med døren ind til læsesalen. Denne mulighed for tilsyn med læsesalen var så væsentlig, at de åbne hylder måtte vige for at sikre dette tilsyn. ${ }^{69}$

\section{Sundhed og opdragelse}

Indretningen af biblioteket sigtede ikke blot mod kontrollen, men havde en sundhedsmæssig betydning. Luftens frie cirkulation gennem en god ventilation blev påpeget som værende af overordentlig stor betydning for at undgå den smålumre lugt, der kunne komme fra folks overtøj. Den engelske bibliotekshistoriker Alistair Black har påpeget, at denne fokusering på den korrekte ventilation og friske 


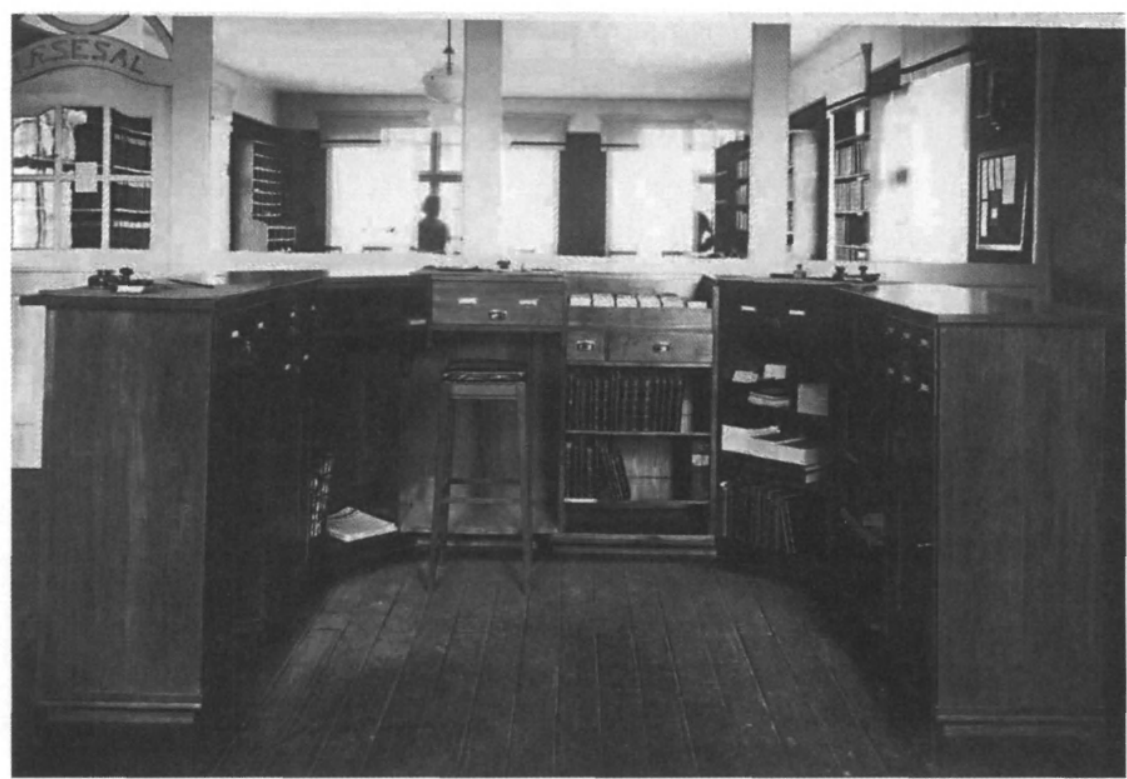

Skranken $i$ Vejle omkring 1917. Begejstringen for dette nye biblioteksinventar strømmede over $i$ H. Hvenegaard Lassens beskrivelse $i$ Bagsamlingsbladet. Hele arbejdsprocessen $i$ biblioteket kunne samles et sted, og samtidig var der udsigt over hele biblioteket. Skranken var frem for alt et praktisk hjalpemiddel for bibliotekaren, og forst senere blev den tilskrevet et fremmedgørende element for låneren. (Danmarks Biblioteksskole. Bibliotekshistorisk Samling)

luft var udsprunget af 1800-tallets medicinske forståelse af luften som smittebærer udtrykt i den såkaldte miasmatiske teori ${ }^{70}$ Til formålet indrettedes særskilte rum til garderoberne, hvor folk kunne aflevere deres overtøj. Hvis muligt endda i trygge hænder hos en tilknyttet garderobebetjent. ${ }^{71}$ Omsorgen for publikums sundhed havde en rent opdragende betydning, hvor især børnene blev opdraget til at vaske hænder på biblioteket, inden de fik adgang til læsning af bøgerne, og dette kunne indlæres som en god vane til brug i hjemmet. $^{72}$ Belysningen i og møbleringen af læsesalen havde både en sundhedsmæssig og opdragende funktion. En korrekt belysning i udlånet som i læsesalen hindrede unødige udgifter samtidig med, at den vænnede læserne på læsesalen fra et overforbrug af lys. Da pub- 
likum mentes hjemmefra at være vant til et større lysforbrug, kunne der kompenseres ved særskilte lamper ved læsepladserne. ${ }^{73}$

Møblerne var dimensioneret efter at skabe en korrekt siddestilling, dels for at styrke rygsundheden, dels med henblik på at indøve en korrekt holdning i ryggen og for at undgå, at læserne sad og hang ved bordene. Hvor der opstilledes fritstående stole (uden borde), var det sundhedsmæssigt bedre at foretrække bænke, da det ville give "en underlig Følelse [...] at sidde lige opret paa en Stol, uden Bord". ${ }^{74}$ For børnelæsesalens vedkommende var møblerne dimensioneret i forhold til børnenes størrelse. Møblernes enkle udformning var betinget af hensynet til rengøringen, og det var vigtigt at undgå for mange ciseleringer og lignende krummelurer, hvor støvet kunne samle sig. Samtidig sikrede den enkle udformning, at læsernes opmærksomhed blev fastholdt ved bøgerne frem for at blive distraheret af for mange finurlige detaljer. At en enkel, solid og smuk indretning virkede befordrende på koncentrationsevnen, var udtryk for et helt nyt syn på bibliotekets æstetiske opdragelse af lånerne, hvor indretningen af læsestuerne på f.eks. Københavns Kommunes Biblioteker i højere grad kan ses som at have været et udslag af blot at stille bøgerne til rådighed. ${ }^{75}$ Bogfyldte reoler havde ligeledes en egen værdi for interiøret, som ikke kun hang sammen med deres egentlige formål: at stille bøgerne til rådighed for det læselystne publikum. Både læsesalens og udlånets indretning skulle udtrykke en vis smag, som gerne skulle smitte af på publikum og være med til at danne dettes smag. ${ }^{76}$

Bibliotekets funktioner fordeltes på forskellige rum, som var kendetegnet ved forskellige måder at arbejde med bogen på: Det tekniske arbejde, som udelukkende omfattede bibliotekaren og bogen, samt det vejledende og oplysende arbejde, der desuden inkluderede låneren - eller brugeren - af bogen. Gennem indretningen af rummene disciplineredes lånerne til at bruge bøgerne $\mathrm{i}$ fornuftens og sundhedens tjeneste og til at betragte bibliotekaren som den nødvendige hjælper, der med faglige argumenter kunne bistå ved valget af egnede bøger til dette formål. Bibliotekets indretning som værksted i bestemte typer af lokaler var rettet mod det mere velstående (middelklasse)publikum, som ikke skulle frastødes af en snav- 
set og mørk atmosfære eller frygte at komme på biblioteket pga. en smittefare fra den mere jævne (og ikke så propre) del af befolkningen. Indretningen udtrykte en række bestemte normer for publikums opførsel og disciplinerede den mindre propre del af befolkningen til at underkaste sig hygiejniske krav om properhed og renlighed. Hele befolkningen disciplineredes gennem de særlige funktioner, som tilknyttedes det enkelte rum, til at være lånere og ved adgangen til læsesalen til at være læsere. Muligheden for at oplyse ånden og videreuddanne sig vha. bibliotekets mange tilbud af bøger i værkstedet medførte samtidig en prægning af normer og regler for god opførsel og smag, der ikke kun gjaldt underklassen, men hele befolkningen.

\section{Konklusion}

Bruddet mellem de to forskellige praksisser for organisering af bibliotekerne gik mellem det private og det offentlige. Det manifesterede sig som en overgang fra den private kreds som udgangspunktet for biblioteket til den geografiske enhed (sognet eller amtet) som bibliotekets udgangspunkt. Dermed løstes problemet med det flertydige landligt funderede sognebibliotek gennem en bymæssig forankring i centralbiblioteket, og biblioteksloven i 1920 definerede entydigt biblioteket ved at fastlægge en række opgaver og funktioner for hver bibliotekstype. Det private initiativ, som udmøntedes i den dannede kreds' grundlæggelse af biblioteket, blev flyttet til et fagligt initiativ hos den uddannede bibliotekar, der tilkendtes en væsentlig position gennem opbygningen af den administrative praksis omkring tilskud og godkendelse af bibliotekerne.

Bruddet mellem det private og det offentlige manifesterede sig i placeringen og indretningen af biblioteket. Placeringen af biblioteket $\mathrm{i}$ byens rum skulle signalere en offentligt situeret institution, og den hjemlige indretning flyttede den private fritidsfornøjelse, læsningen, over i det offentlige rum. Dette gjaldt ikke kun den oplysende læsning, der foregik på læsesalen, for gennem udlånslokalets indretning med de åbne hylder og den kontrollerende og vejledende bibliotekar sattes fornøjelseslæsningen $i$ en ramme af at være offentligt relevant. Indretningen af biblioteket virkede disciplinerende 
på befolkningens læsevaner ved at vægte den faglige oplysning på læsesalen, og samtidig prægedes lånerne til at efterleve en række normer, der havde deres udspring i en borgerlig forståelse af mennesket. Normen for den oplyste samfundsborger prægedes gennem sammensætningen af håndbiblioteket og det øvrige udbud af materialer (aviser og tidsskrifter), hvorved den kritiske stillingtagen opdyrkedes. Stilhedsklausulen og vægten på den sunde og hygiejniske indretning af bibliotekets rum understøttede forestillingen om det rolige og sunde menneske. Det var ikke kun bibliotekssagen, der trængte til organisation - det var hele befolkningen.

\section{NOTER}

1. H. O. Lange: Bibliotekssagen uden for København. Foredrag paa Biblioteksmødet i Aarhus den 4. August 1909. I: Bibliotekarforeningens Smaaskrifter, 1909 , s. 7.

2. Harald Hvenegaard Lassen: De danske folkebibliotekers historie 1876-1940, 1962, s. 9-25, 181-190. - Marton de Hartyani: Sognebiblioteksundersøgelsen 1885. I: Bibliotekshistorie, 1985, s. 49-74. - Steffen Høgh: Danmarks første bibliotekslov. Om tilblivelsen af biblioteksloven af 5. marts 1920 samt et efterspil. I: Bibliotekshistorie, 1995, s. 74-99.

3. Artiklen er en del af en større afhandling om de danske folkebibliotekers historie i perioden 1880-1920. Det er derfor kun nogle enkelte aspekter af organisationsdebatten, der her inddrages, ligesom litteraturen, bibliotekaren og låneren kun inddrages meget sporadisk.

4. For nærmere om diskontinuitet og brud se Michel Foucault: The Archaeology of Knowledge, 2001 (1969), og samme forfatter: Ordene og Tingene. En arkæologisk undersøgelse af videnskaberne om mennesket, 1999 (1966). Desuden Michel Foucault: Überwachen und Strafen. Die Geburt des Gefängnisses, 1994 (1975) og samme forfatter: Die Ordnung des Diskurses, 2000 (1972).

5. Kristian Hvidt: Det folkelige gennembrud og dets mænd 1850-1900. Gyldendal og Politikens Danmarkshistorie, bd. 11. Red. Olaf Olsen, 1990, s. 211.

6. Hvenegaard Lassen, 1962, s. 17-21.

7. Hvenegaard Lassen, 1962, s. 17-21.

8. N. Neergaard: Kommunens Folkebiblioteker. I:Tilskueren, 1886, nr. 3, s. 407414. - Hvenegaard Lassen, 1962, s. 36-40. 
9. For sognebiblioteksundersøgelsen i 1885 se: Rigsarkivet [herefter:RA] 2073, Folkelige Bogsamlinger nr. 2-6, A5-9. For de øvrige undersøgelser henvises til C.A. Thyregod: Om sognebogsamlinger. I: Skoletidende, 1876, nr. 3, s. 1720; nr. 4, s. 25-33; nr. 5, s. 41-45; nr. 6, s. 49-51; nr. 7, s. 57-61. Desuden til Berlingske Tidende, 1878 (gengivet i de Hartyani, 1985, s. 63-70) samt til Joakim Larsen: Meddelelser om forskjellige Forhold vedrørende Skolevæsenet i Danmark, Kbh. 1880, 73 s.

10. RA 2073, Folkelige Bogsamlinger nr. 2-6, A5-9. Spørgeskemaets udformning (spørgsmålene 1-2, 3, 8, 10).

11. M. Steenstrup: Om Sogne- og Skolebogsamlinger. Foredrag holdt ved Danmarks Lærerforenings almindelige Skolemøde i august 1880, 1880, s. $6 f$ samt Larsen, 1880 , s. $57 \mathrm{f}$.

12. Ministerialtidende for Kongeriget Danmark. Forskjellige Meddelelser. Beretning fra Komiteen til Understøttelse af Sogne- og lignende Bogsamlinger om Sogne- og Skolebogsamlinger, 1889, s. 915.

13. de Hartyani, 1985, s. 65f. Se endvidere Larsen, 1880, s. 56; Ministerialtidende, 1889, s. 917; Steenstrup, 1880, s. 4 og 8ff.; Thyregod, 1876, nr. 3, s. 18.

14. Larsen, 1880, s. 58 og 61; Steenstrup, 1880, s. 4.

15. de Hartyani, 1985, s. 67-68; Larsen, 1880, s. 61; Steenstrup, 1880, s. 4 og 6.

16. RA 2073, Folkelige Bogsamlinger nr. 2-6, A5-9. Spørgsmål 8.

17. Thyregod, 1876, nr. 7 , s. 58.

18. Thyregod, $1876, \mathrm{nr} .7$, s. 58 . Senere blev det opfattet som langt mere fordelagtigt at knytte bibliotekarhvervet til læreren for at sikre kontinuiteten i bogsamlingens ledelse. Se f. eks. Johannes Grønborg:Vore Landsbybogsamlinger, 1912, s. 26-27.

19. Thyregod, 1876, nr. 3, s. 20 samt nr. 4, s. 26.

20. Steenstrup, 1880 , s. 9.

21. Skolen i Danmark 1500-1980'erne. Red. af Harry Haue, Ellen Nørgaard, Vagn Skovgaard-Petersen, Johnny Thiedecke, 1986, s. 43.

22. Se f.eks. indholdsfortegnelsen til Gyldendals Danmarkshistorie, hvor 3. kapitel hedder Samfundets organisering. Red. af Søren Mørch, Bd. 6: Tiden 1864-1914. Af Lorenz Rerup, 1989.

23. Bibliotekstilsynets bekendtgørelse: Statens Bibliotekstilsyns Publikationer, nr. 5, 1921. Her $\$ \int 1,5$ og 7. Se desuden forhandlingerne i Folketinget, Rigsdagstidende, 1919-1920. Fremsættelse af lovforslag 28.1.1920, 1. behandling 4.2.1920, 2. behandling 18.2.1920 samt 3. behandling 20.2.1920.

24. Se 1. behandling i folketinget, Rigsdagstidende 1919-1920 samt Betænkning afgivet af det af Undervisningsministeren under 31. oktober 1919 nedsatte Udvalg, s. 6.

25. RA 2073, Komiteens Beretninger m.m. 1911-1919, nr. 23: C43 Erklæringer afgivet til ministeriet (andragende fra Dansk Biblioteksforening dateret 12.3. 1917). 
26. Bibliotekstilsynets bekendtgørelse $1921 \rrbracket 6$ og Biblioteksloven $1920, \rrbracket 5$. Biblioteksloven findes ligeledes i Statens Bibliotekstilsyns Publikationer, nr. 5, 1921

27. RA 2073, Komiteens Beretninger m.m. 1911-1919 nr. 23: C43 Erklæringer afgivet til ministeriet (andragende fra Dansk Biblioteksforening dateret 12.3. 1917).

28. Biblioteksloven $\iint 8-10$.

29. RA 2073, Komiteens Beretninger m.m. 1911-1919 nr. 23: C43 Erklæringer afgivet til ministeriet (andragende fra Dansk Biblioteksforening dateret 12.3. 1917).

30. Undervisningsministeriets bekendtgørelse, $₫ 1$. I: Statens Bibliotekstilsyns Publikationer, nr. 5, 1921 samt Forslag til biblioteksvedtægter, der findes i Statens Bibliotekstilsyns Publikationer, 1921, s. 14-19.

31. Bibliotekstilsynets bekendtgørelse, $\ 6$. - Forslag til Instruks for Bibliotekaren ved et større Bibliotek, $\mathbb{\int}$ 4. I: Statens Bibliotekstilsyns Publikationer, nr. 5, 1921.

32. Biblioteksloven $\$ \uparrow 1-4$ samt Bibliotekstilsynets bekendtgørelse $\ 2$.

33. Undervisningsministeriets bekendtgørelse $\$ 3$, stk. b. I: Statens Bibliotekstilsyns Publikationer, nr. 5, 1921 samt RA 2073, Komiteens Beretninger m.m. 1911-1919 nr. 23: C43 Erklæringer afgivet til ministeriet (andragende fra Dansk Biblioteksforening dateret 12.3. 1917).

34. Bibliotekstilsynets bekendtgørelse $\ 3$, stk. 1 .

35. Instruks for Bibliotekaren ved et større Bibliotek, $\int \$ 1-14$.

36. Bibliotekstilsynets bekendtgørelse, $\int 6$, stk. a.

37. Biblioteksloven $₫ 4$.

38. Ministeriets bekendtgørelse $₫ 3$, stk. b.

39. RA 2073, Komiteens Beretninger m.m. 1911-1919 nr. 23: C43 Erklæringer afgivet til ministeriet (andragende fra Dansk Biblioteksforening dateret 12.3. 1917).

40. RA Privatarkiver 5082, pk. 5 Diverse korrespondancer m.m. Brev af 3.2.1915

41. A. S. Steenberg: Folkebogsamlinger. Deres Historie og Indretning, 1900, s. 36.

42. Steenstrup, 1880, s. 4; Thyregod, 1876, nr. 4, s. 30. Samt Steenberg, 1900, s. 94.

43. RA 2073, Kopibøger nr. 37: D8 nr. 410 (3.10.1916)

44. V. Grundtvig: Bibliotekssagen i Danmark. Dens Maal og Midler, 1910, s. 45.

45. Læserbrev i Politiken, 10.11.1885 samt Neergaard, 1886, s. 408.

46. Se eks. Lange, 1909, s. 5-6.

47. For det følgende bygges i al væentlighed på Lærebog i Biblioteksteknik. Foreløbig udgave, 1922, s. 130-161, her s. 130-134. RA 2073, Korrespondance mellem Steenberg og Weis 1899-1910 nr. 8: B1 (26.2.1902). RA 2073, Komiteens Beretninger m.m. 1911-1919 nr. 23: C43 Erklæringer af- 
givet til ministeriet (andragende fra Dansk Biblioteksforening dateret 12.3. 1917). Se Biblioteksloven, $\ 2$ for den endelige fastlæggelse af statens politik på dette område.

48. Biblioteksteknik, 1922, s. 150.

49. A. S. Steenberg: Moderne Biblioteksarbejde. I:Vore Folkebogsamlinger. Deres Nytte og Nødvendighed, 1915, s. 11.

50. Biblioteksteknik, 1922 , s. 150.

51. Fr. Orluf: En ny Bibliotekstype. Biblioteket for Vejle Amt og By. I: Bogsamlingsbladet, 3. årg. 1908-1909, s. 49-55 og RA 2073, Kopibøger, nr. 36: D4 brev nr. 265 (10.5.1912).

52. RA 2073, Kopibøger, nr. 36: D5 nr. 476-477 (26.3.1914) og D6 nr. 302 (2.11.1914); nr. 37: D7 nr. 128 (17.5.1915) og D8 nr. 181-182 (19.4.1916); nr. 38: D9 nr. 369 (6.9.1917) samt D10 nr. 154 (24.1.1918). For Vejen Bibliotek, se Thomas Døssing: Vejen Bibliotek. I: Bogvennen, 6. årg., nr. 3, 1916, s. 104.

53. RA 2073, Kopibøger nr. 38: D9 nr. 218-219 (2.5.1917) samt nr. 250 (21.5.1917).

54. Denne opbygning var ikke et nyt fænomen, men havde rødder tilbage til indretningen af klostrenes scriptorier.

55. RA 2073, Kopibøger nr. 35: D2 nr. 12 (23.2.1909) samt Lærebog i Biblioteksteknik, 1922, s. 137.

56. Lærebog i Biblioteksteknik, 1922, s. 138-139.

57. RA 2073, Kopibøger nr. 35: D3 nr. 323 (18.8.1911)

58. Lærebog i Biblioteksteknik, 1922, s. 102. Oversigt over egnede håndbøger findes s. 104-105.

59. Da synet på avislæsningen i høj grad var betinget af synet på låneren eller for læsesalens vedkommende læseren, skal dette emne ikke yderligere behandles her. Lærebog i Biblioteksteknik, 1922, s. 99.

60. RA 2073, Indkomne breve, nr. 40: D15 breve fra Banke til Steenberg 19131918 (8.4.1916) samt nr. 39: D13(a) breve fra Bjerre til Steenberg 1902-1909 (24.5.1905) og Døssing, 1916, s. 104.

61. Bogsamlingsbladet, 3. årg., 1908-09, s. 67. Lange, 1909, s. 5 f.

62. Thyregod, 1876, nr. 4, s. 30 samt RA 2073, Folkelige Bogsamlinger nr. 2-6: A5-9, spørgsmål nr. 5.

63. Chr. Christensen: Folkeligheden i Folkebibliothekerne. I: Politiken, 11.7.1887. Skribenten redegjorde her for umuligheden af at komme til at låne værker af de progressive debattører Neergaard og Trier.

64. En kort introduktion til de åbne hylder blev givet af Steenberg, 1900, s. 25. Samme: Fra fremmede Lande. I: Bogsamlingsbladet, 2. årg., 1907-08, s. 8889. - Samme: Hvor langt er vi komne og hvad nu? I: Beretning om det 1. almindelige danske biblioteksmøde på landsudstillingen i Ărhus, 3.-4. august 1909, s. 4-10. Indeholder referat af diskussionen. - RA 2073, Indkomne bre- 
ve, nr. 40: D18 breve til Steenberg fra enkeltpersoner (24.7.1909). Som et kuriosum kan det nævnes, at fælleskønsformen 'katalogen' som fagudtryk ikke havde vundet indpas overalt. Langt de fleste anvendte som regel intetkønsformen.

65. Som en modsætning til dette argument blev det i "Lærebog i Biblioteksteknik" fremhævet, at de mest anvendte bøger skulle placeres i udlånslokalet, medens de mindst anvendte kunne placeres i magasinet, hvortil der ikke var direkte adgang for lånerne. Lærebog i Biblioteksteknik, 1922, s. 134.

66. Se f. eks. RA 2073 Kopibøger nr. 37: D7 nr. 128 (17.5.1915) og nr. 38: D9 nr. 218-219 (2.5.1917). Lærebog i Biblioteksteknik, 1922, s. 144.

67. Hvenegaard Lassen: Udlaansskranken i Vejle, I: Bogsamlingsbladet, 12. årg., 1917, s. 47-48.

68. Bibliotekernes ordensregler opstillede yderligere klare normer for opførsel på biblioteket, men de bliver ikke inddraget her, da der fokuseres på bibliotekets rum som den disciplinerende kraft.

69. RA 2073, Kopibøger nr. 36: D4 nr. 158-159 (ca. 8.3.1912); nr. 37: D7 nr. 128 (17.5.1915) og nr. 38: D9, nr. 218-219 (2.5.1917). Lærebog i Biblioteksteknik, 1922, ss. 136, 150 samt 157-158.

70. Alistair Black: The Open Access Revolution in British Public Libraries: Consumer Democracy or Controlling Discourse? I: Librarians World. The Independent Journal of Librarians, 3. årg., nr. 5, 1994, s. 7

71. Lærebog i Biblioteksteknik 1922, s. 143. Det fremhæves her, at dette kun er gennemførligt ved større biblioteker.

72. Dette blev i samtiden humoristisk forstået som en renselsesfest. Se Ibald [Viggo Cavling]: Da Børnebiblioteket blev stormet. I: Politiken, 10.2.1916.

73. Lærebog i Biblioteksteknik, 1922, s. 145.

74. RA 2073, Kopibøger nr. 35: D2 nr. 12 (23.2.1909).

75. Folkebibliotheker. I: Politiken, 10.11.1885. Se desuden Neergaard, 1886, s. 409.

76. RA privatarkiv 5082, pk. 1 Korrespondance 1900-1929 (brev fra 6.10.1919). Carl Jørgensen: Hvorledes man skaber et godt Biblioteksinteriør. I: Bogens Verden, 2. årg., 1919-1920, s. 207-208. 